九州大学学術情報リポジトリ

Kyushu University Institutional Repository

\title{
Comparative Studies of Food Habits and Digestive Tracts in Two Apodemus Species
}

Shioya, Katsunori

Mori, Takayuki

Zoological Laboratory, Faculty of Agriculture, Kyushu University

Shiraishi, Satoshi

Zoological Laboratory, Faculty of Agriculture, Kyushu University

https://doi.org/10.5109/24056

出版情報：九州大学大学院農学研究院紀要. 38 (3/4)，pp.243-254，1994-03. Kyushu University バージョン：

権利関係 : 
J. Fac. Agr., Kyushu Univ., 38 (3•4),243-254 (1994)

\title{
Comparative Studies of Food Habits and Digestive Tracts in Two Apodemus Species
}

\author{
Katsunori Shioya*, Takayuki Mōri and Satoshi Shiraishi
}

Zoological Laboratory, Faculty of Agriculture, Kyushu University 46-06, Fukuoka 812, Japan

(Received January 14, 1994)

\begin{abstract}
Feeding experiments using three pairs of food items, analysis of the scaling of digestive organs and microscopic observation were examined in two woodland rodent species, Apodemus argenteus and A. speciosus. Comparing the values of selective indices between acorns and three species of insects, it was shown that $\mathbf{A}$. argenteus has more intensive preference to insects than does A. speciosus. Both the mean ratio of the caecum length to stomach and intestine length (CL/TL) and the ratio of caecum length to the small intestine length (CL/SIL) in A. speciosus were significantly larger than those in $A$. argenteus. Compared to $\mathbf{A}$. speciosus, distributions of goblet cells stained with PAS in $\mathbf{A}$. argenteus were dense and homogeneous at most of positions of the small intestines. These characteristics in the small intestine suggest that A. argenteus depends on more homogeneous and proteinic foods, and support the results from our feeding experiments. From what described above, it was implied that these differences in potential food habits are related to the characteristics of foraging behavior, habitat utilization and territoriality in the two Apodemus species.
\end{abstract}

\section{INTRODUCTION}

Studies of food habits in small mammals have been mainly based on microscopic analyses of feces or stomach contents and on preference experiments in the laboratory (Hansson, 1985). In Apodemus argenteus and A. speciosus, which are Japanese woodland rodents, several reports on analyses of stomach contents (Mizushima and Yamada, 1974; Tachikawa and Murakami, 1976) reveal that the two species have both granivorous and insectivorous characteristics. Still, research on the food habits of the two species often fails to illuminate the differences between the two species: however, it is accepted that $A$. argenteus depends on animal food more than $A$. speciosus (Maeda et $a l .$, 1984). Laboratory experiments on food preference among woodland rodents showed that quality and/or abundance of usable foods affect the diet selection (Hansson, 1985). It was shown that availability of foods in both the laboratory and field experiments affects the diet choice of Apodemus species (Holisova, 1975; Sone, 1990). Therefore, there is a great need for further examination of experimental conditions concerning combination and availability of food items to objectively explain differences in food habits between the two species.

$A$. argenteus and $A$. speciosus are sympatric species with segregated microhabitats, which is explained as a mechanism for reducing interspecific competition (Shioya et al., 1990). Difference in food habits are an important factor in facilitating coexistence of

*Present address: Wildlife Ecology Laboratory, Forestry and Forest Products Research Institute, Ministry of Agriculture, Forestry and Fisheries, Ibaraki 305, Japan 
sympatric species (M’Closkey, 1976; Rosenzweig, 1981). Namely, differences in microhabitat usage in small mammals depend on food habit or foraging behaviors (Rosenzweig, 1991). Therefore, understanding of the histology and histochemistry of digestive organs is necessary for revealing differences in the trophic characters of small mammals.

In these two species, most of the studies on the digestive organs have used macroanatomical observations. Although some studies analysed the relationships between the ratio of caecum length to small intestine length and food habits (Miyao et al., 1960; Maeda et al., 1984), histological analyses were never done. Mucilage cells, which serve in the protection of mucosal epithelium in the stomach and intestines, are related to the activity of digestion of protein in the diet (Martin, 1961). There is hence the possibility of explaining differences in food habits between species by numerical analyses of mucilage cells. However, most studies only compare gastric histology among species with extremely various food habits (Horner et al., 1965 for Rodentia; Kamiya and Pirlot, 1975 for Chiroptera; Luthje, 1976 for Rodentia; Suzuki et al., 1986 for Primates). Because no appreciable difference in interspecific macroanatomical morphology was found, little attention has been given to the small intestine, whose real functions are absorption and digestion.

The aim of this paper is to compare the preference to animal food of the two Apodemus species based on the results of feeding experiments with three pairs of acorns and insects, and to discuss the histological characters of the gastric organs and small intestines, which are related to the food habits in both species.

\section{MATERIALS AND METHODS}

\section{Feeding experiments}

The preference experiment trials were conducted in an enclosure $(1: \mathrm{w}: \mathrm{h}=30 \times 60$ x $40 \mathrm{~cm}$ ). The temperature was maintained at approximately $20^{\circ} \mathrm{C}$. Numbers and kinds of food items used in each of the experiment were as follows: 30 acorns of Quercus glauca and 30 beetles of Melolontha satsumaensis in experiment 1; 10 acorns of Q. glauca and 30 domestic flies Musca domestica in experiment 2; 30 acorns of Q. glauca and another 30 acorns which included the parasitic larvae of Curculio sikkimensis in experiment 3. In each of the experiments, ten wild-caught mice (5 $\sigma^{7} \sigma^{7}: 5$ 웅 $)$ of each of the two Apodemus species were used. All adult Apodemus mice used in these experiments were trapped at Mt. Tachibana-yama $(367 \mathrm{~m})$ north of Fukuoka City in April 1989. Each of the individuals was starved for $12 \mathrm{hrs}$ prior to the trials and introduced singly into the enclosure at $1900 \mathrm{~h}$. The enclosure had two kinds of food items and water. Consumption was recorded and cached items were checked on the following day at $0100 \mathrm{~h}$. Trials in each experiment were repeated three times for each individual. Mean values of both Ivlev's selective index (Ivlev, 1961) and Jacobs's index (Jacobs, 1974) were calculated for each species, and compared between the species using Mann-Whitney U-tests.

\section{Histological methods}

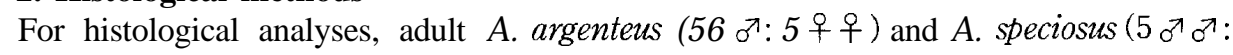


5 우우) were also captured in November 1990 at a location similar to that in the preference experiments described above. The gastrointestinal tract was extracted from the abdominal cavity after killing individuals by etherization. For macroanatomical measurements of digestive tracts, the stomach and intestine length (TL), small intestine length (SIL), and caecum length (CL) in fresh condition were recorded. Stomachs and small intestines to be used for comparative histological studies were fixed in Bouin's fixative. For the gastric organs, segments were taken from both the cardiac and fundic regions. For the small intestines, segments of $5 \mathrm{~mm}$ length were taken at each of five positions at 4, 20, 40, 60 and $80 \%$ of the length of the tracts from the proximal to the distal side. One group of these segments was embedded in paraffin wax after dehydration, and then sectioned at $6 \mu \mathrm{m}$ and stained with haematoxylin and eosin. The others were embedded in Technovit 7100 (Kulzer Co., Ltd.) and sectioned at $4 \mu \mathrm{m}$, employing haematoxylin and periodic acid Schiff (PAS) technique for microscopic observation of goblet cells. To statistically analyse differences in the function of proteinic digestion of food-stuff in the small intestines, numbers of the goblet and other cells were counted at ten points at each of the villi and crypts per segment. In the two species, frequency of appearance of the goblet cells was compared, i.e. the ratio of goblet cells to all cells.

\section{RESULTS}

\section{Feeding experiments}

In experiment 1 , the mean numbers of acorns and M.satsumaensis per trial selected by A. argenteus were 1.5 and 2.6, respectively, while A. speciosus selected 4.9 acorns and 4.4 beetles per trial on average (Table 1). Both species almost exclusively attacked at the basal part of the hemelytra of $M$. satsumaensis and fed on the abdominal material, excluding the cuticle. Mean values of both Ivlev's selective index and Jacobs's index were

Table 1. Results of feeding experiment 1 comparing two Apodemus species, using acorns of Quercus glauca and adults of Melolontha satsumaensis as diet.

\begin{tabular}{|c|c|c|c|c|}
\hline & \multicolumn{2}{|c|}{ A. argenteus } & \multicolumn{2}{|c|}{ A. speciosus } \\
\hline & acorn & $M$. satsumaensis & acorn & $M$. satsumaensis \\
\hline $\mathrm{n}$ & 1.5 & 2.6 & 4.9 & 4.4 \\
\hline ri & 0.366 & 0.634 & 0.527 & 0.473 \\
\hline pi & 0.5 & 0.5 & 0.5 & 0.5 \\
\hline $\mathrm{Ei}$ & -0.155 & 0.118 & $\begin{array}{r}0.026 \\
-p<0.001\end{array}$ & $\begin{array}{c}-0.028 \\
\end{array}$ \\
\hline Di & -0.268 & $\begin{array}{c}p<0.001- \\
0.268 \\
L\end{array}$ & $\begin{array}{l}0.054 \\
-p<0.001\end{array}$ & $\begin{array}{c}-0.054 \\
\end{array}$ \\
\hline
\end{tabular}

$\mathrm{n}$, mean numbers of food items eaten; r, mean proportions of food items eaten in diet; $p_{i}$, mean proportions of food items in food; $E_{i}$, means of Ivlev's selective index $=\frac{r_{i}-p_{i}}{r_{i}+p_{i}} ; D_{i}$, means of Jacobs's index $=\frac{r_{i}-p_{i}}{r_{i}+p_{i}-2 r_{i} p_{i}} \quad$ Significant differences are estimated using the Mann- Whitney U-test. 
significantly different between the two species (U-tests, $p \mathrm{~s}<0.001)$ : A. argenteus more intensively selected $M$. satsumaensis than $\operatorname{did} A$. speciosus.

In experiment 2 , the mean numbers of acorns and $M$. domestica selected per trial by A. argenteus were 1.5 and 10.6, respectively, while these values were 7.0 and 11.0 in A. speciosus. Also, the parts of the fly bodies on which the mice began to feed were different in each attacked fly. The flies were consumed almost completely except for the indigestible wings and cuticle segments. Results in experiment 2 were similar to those obtained in experiment 1: mean values of both Ivlev's selective index and Jacobs's index were significantly different between the two species (U-tests, $p s<0.001$ ). This shows that $A$. argenteus selected $M$. domestica more strongly than did A. speciosus (Table 2).

Table 2. Results of feeding experiment 2 comparing two Apodemus species, using acorns of Q. glauca and adults of Musca domestica as diet.

\begin{tabular}{|c|c|c|c|c|c|}
\hline & \multicolumn{2}{|c|}{ A. argenteus } & \multicolumn{3}{|c|}{ A. speciosus } \\
\hline & acorn & M. domestica & acorn & & M. domestica \\
\hline $\mathrm{n}$ & 1.5 & 10.6 & 7.0 & & 11.0 \\
\hline$r_{i}$ & 0.122 & 0.877 & 0.388 & & 0.611 \\
\hline $\mathrm{Pi}$ & 0.25 & 0.75 & 0.25 & & 0.75 \\
\hline$E_{i}$ & -0.344 & $\begin{array}{c}p<0.001- \\
0.078 \\
\end{array}$ & $\begin{array}{r}0.040 \\
<\quad 0\end{array}$ & $0 \quad 0$ & $\begin{array}{ll} & -0.019 \\
0 & 1\end{array}$ \\
\hline $\mathrm{D}_{\mathrm{i}}$ & $\begin{array}{c}7 \\
-0.454\end{array}$ & $\begin{array}{l}<0.001- \\
0.454 \\
\longleftarrow\end{array}$ & $\begin{array}{c}0.312 \\
p<0.001\end{array}$ & 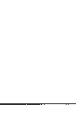 & $\begin{array}{c}-0.312 \\
-\end{array}$ \\
\hline
\end{tabular}

See Table 1 for explanations of symbols.

In experiment $3, A$. argenteus selected 1.1 sound acorns and 9.5 acorns parasitised by larvae of C. sikkirnensis per trial on average, whereas A. speciosus selected 4.6 and 9.8 , respectively. The larvae were removed from acorns and completely consumed by both species. Mean values of the two indices of each of the food items were significantly different between the two species (U-tests, $p s<0.01-0.001$ ). A argenteus

Table 3. Results of feeding experiment 3 comparing the two Apodemus species, using acorns of $Q$. glauca and the ones including parasitised by larvae of Curuculio sikkimensis as diet.

\begin{tabular}{|c|c|c|c|c|}
\hline & \multicolumn{2}{|c|}{ A. argenteus } & \multicolumn{2}{|c|}{ A. speciosus } \\
\hline & acorn & C. sikkimensis & acorn & C. sikkimensis \\
\hline $\mathrm{n}$ & 1.1 & 9.5 & 4.6 & 9.8 \\
\hline $\mathrm{r}_{\mathrm{i}}$ & 0.103 & 0.896 & 0.319 & 0.680 \\
\hline $\mathrm{Pi}$ & 0.5 & 0.5 & 0.5 & 0.5 \\
\hline $\mathrm{E}_{\mathrm{i}}$ & -0.656 & $\begin{array}{c}p<0.001- \\
0.283 \\
L\end{array}$ & $\begin{array}{l}-0.220 \\
<0.001\end{array}$ & $\begin{array}{r}0.152 \\
.\end{array}$ \\
\hline $\mathrm{D}_{\mathrm{i}}$ & $\begin{array}{c}\lceil \\
-0.792\end{array}$ & $\begin{array}{c}-p<0.001- \\
0.792 \\
L\end{array}$ & $\begin{array}{l}-0.361 \\
<0.01\end{array}$ & $\begin{array}{c}0.361 \\
. \\
\end{array}$ \\
\hline
\end{tabular}

See Table 1 for explanations of symbols. 
more strongly selected C. sikkimensis in comparison with A. speciosus (Table 3).

\section{H istology of stomachs and small intestines}

The mean lengths from stomach to rectum (TL) were $387.3 \mathrm{~mm}$ (s.d. $=22.1$ ) in A. argenteus and $490.4 \mathrm{~mm}(\mathrm{~s} . \mathrm{d} .=41.0)$ in A. speciosus (Table 4). Mean ratios of the small intestine length to these total lengths $(\mathrm{SIL} / \mathrm{TL})$ were 0.679 (s.d. $=0.099)$ in A. argenteus

Table 4. Comparison of measurements of digestive tracts between the two Apodemus species on the basis of means (s.d.) of stomach and intestine length (TL), small intestine length (SIL), caecum length (CL), and cube root of body weight $(\sqrt[3]{\mathrm{BW}})$.

\begin{tabular}{|c|c|c|c|}
\hline & A. argenteus & A. speciosus & $P$ \\
\hline $\mathrm{TL} \mathrm{mm}$ & $387.3 \quad(22.1)$ & $490.4(41.0)$ & \\
\hline $\mathrm{SIL} / \mathrm{TL}$ & $0.679 \quad(0.099)$ & $0.673 \quad(0.135)$ & $\mathrm{ns}$ \\
\hline $\mathrm{CL} / \mathrm{TL}$ & $0.091 \quad(0.011)$ & $0.101 \quad(0.013)$ & $<0.05$ \\
\hline $\mathrm{CL} / \mathrm{SIL}$ & $0.134 \quad(0.032)$ & $0.150 \quad(0.073)$ & $<0.05$ \\
\hline $\mathrm{TL} / \sqrt[3]{\mathrm{BW}}$ & $146.4(9.03)$ & $147.8(11.50)$ & $\mathrm{ns}$ \\
\hline SIL $/ \sqrt[3]{\mathrm{BW}}$ & $99.4 \quad(6.18)$ & 99.5 (7.74) & ns \\
\hline $\mathrm{CL} / \sqrt[3]{\mathrm{BW}}$ & $14.5(0.90)$ & $14.9(1.16)$ & ns \\
\hline
\end{tabular}

ns, not significant by using Mann-Whitney U-test.

and 0.673 (s.d. $=0.135$ ) in A. speciosus, and did not differ significantly (U-tests, $p>0.05$ ). On the other hand, the mean ratios of the caecum length to the total length (CL/TL) were 0.091 (s.d. $=0.011$ ) in A. argenteus and 0.101 (s.d. $=0.013$ ) in A. speciosus, and the ratios of caecum length to the small intestine length $(\mathrm{CL} / \mathrm{SIL}$ ) were 0.134 (s.d. $=0.032$ ) and 0.150 (s.d. $=0.073$ ), respectively, and there were significant differences in these ratios between the species $(U$-tests, $p \mathrm{~s}<0.05$ ). Additionally, all of the ratios of TL, SIL, and CL to cube roots of body weight were not significantlly different between the two species (U-tests, $p \mathrm{~s}>0.05$ ).

Microscopic observations in the fundic region of the gastric organs revealed that maximum ratios of thickness of the Tunica muscularis to the whole cross layer were approximately $15 \%$ in A. argenteus and $20 \%$ in A. speciosus. Chief cells, which were stained violet with haematoxylin, were sparse in the neck region of the gastric gland in both species, while they were relatively dense in the basal region. The ratios of the thickness of this high density region to the depth of the gastric gland were $50 \%$ in A. argenteus and $30 \%$ in A. speciosus. Parietal cells, including granules stained red with eosin, were scattered in both species, and the distribution patterns of parietal cells were not different. In the cardiac region, the ratio of thickness of mucous layer to the whole of the stomach layer ranged from $14-20 \%$ in both species. Maximum ratios of Tunica muscularis to thickness of the whole cross layer were approximately $25 \%$ in $\mathbf{A}$. argenteus and $30 \%$ in A. speciosus. Significant differences in these values were not found between the two species (U-tests, $p \mathrm{~S}>0.05$ ).

On the basis of microscopic observations of the small intestines, the villi region was shown to be 3 to 5 times thicker than the Tunicamuscularis in both species and the species did not essentially differ in the scaling of villi. In the basal region of the crypts 


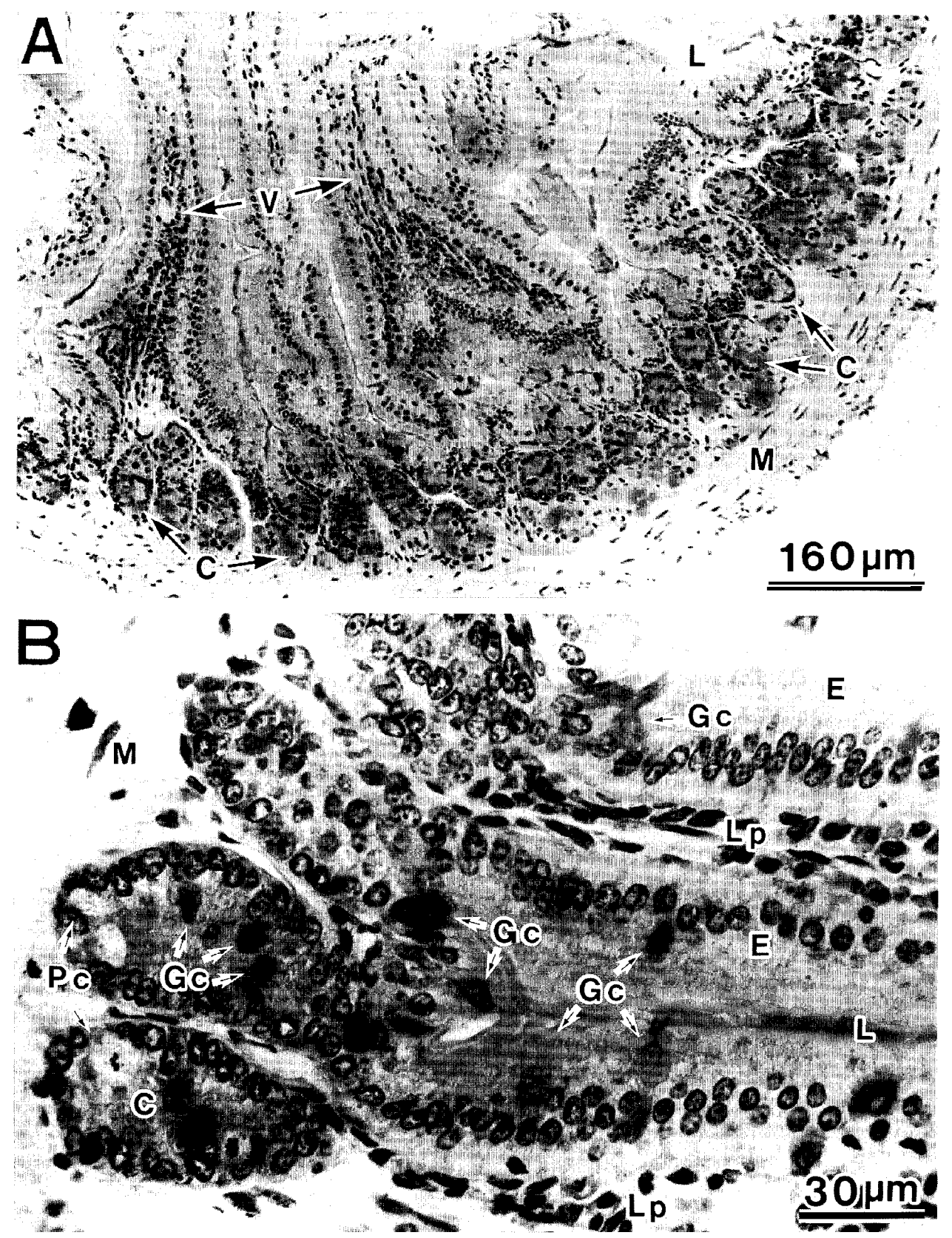

Fig. 1. Photomicrographs showing the small intestine of Apodemusargenteus stained with PAS and haematoxylin. A, Cross section at the jejunum; B, Cross section at the ileum. Note the presence of many goblet cells (Gc) in deeper site of crypts (C). E, epithelium; L, lumen; Lp, lamina propria mucosae; M, Tunica muscularis; Pc, Paneth's cell; V, villi. 

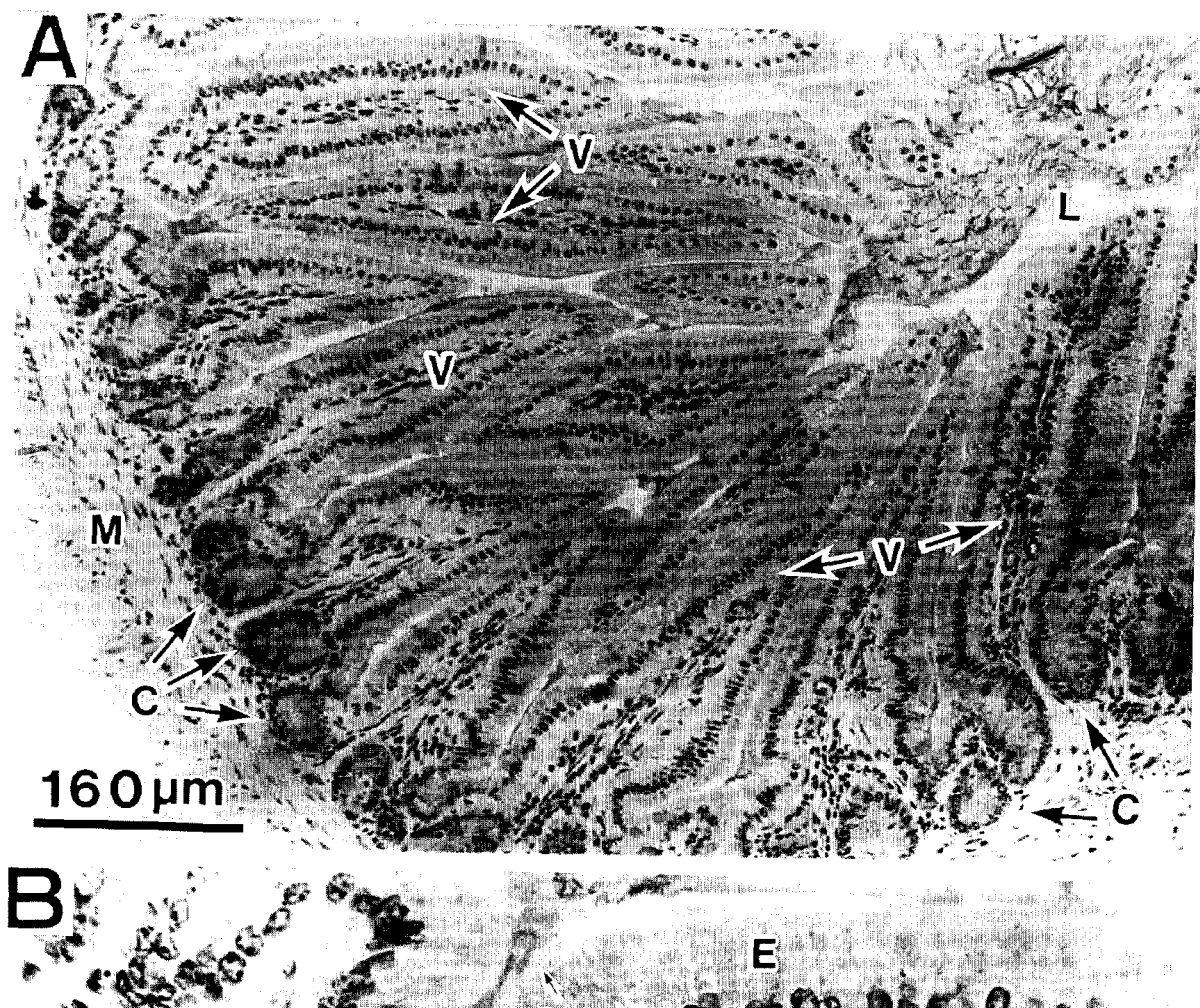
- $\cos ^{2} \mathrm{~s}$

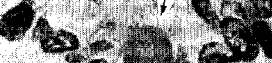
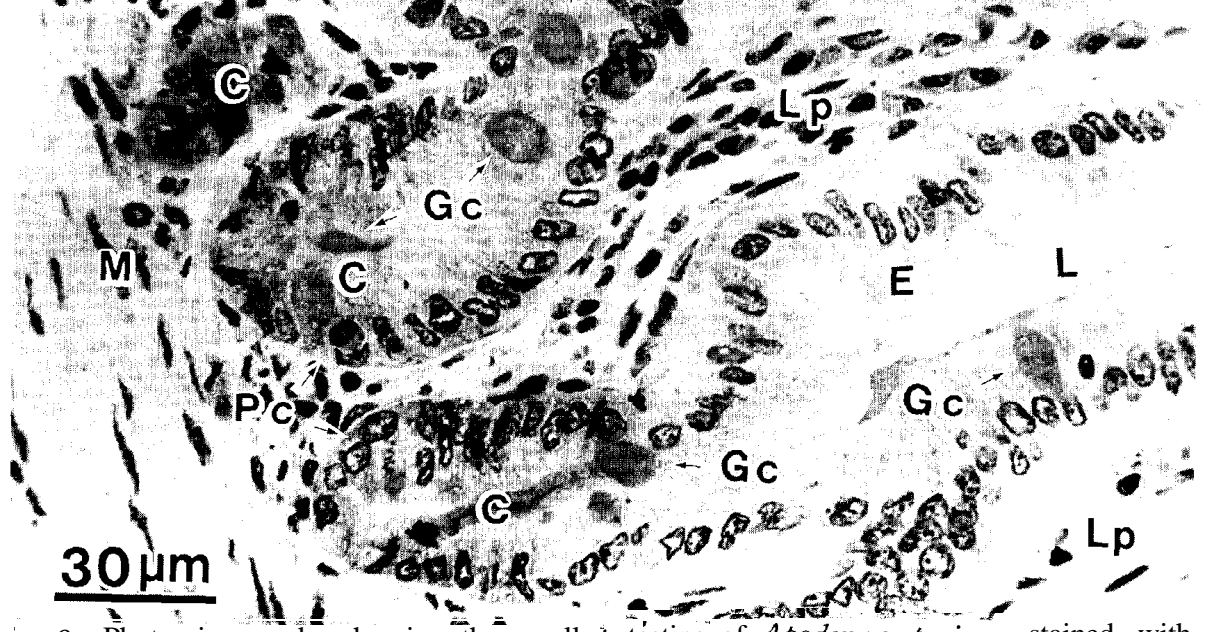

Fi ig. 2. Photomicrographs showing the small in testine of Apodemus speciosus stained with PAS and haematoxylin. A, Cross section at the jejunum. Note the sparse presence of goblet cells $(\mathrm{Gc})$ in deeper site of crypts $(\mathrm{C}) ; \mathrm{B}$, Cross section at the ileum. Goblet cells are dense in comparison with those at the jesunum. E, epithelium; L, lumen; Lp, lamina propria mucosae; M, Tunica muscularis; Pc, Paneth's cell; V, villi. 

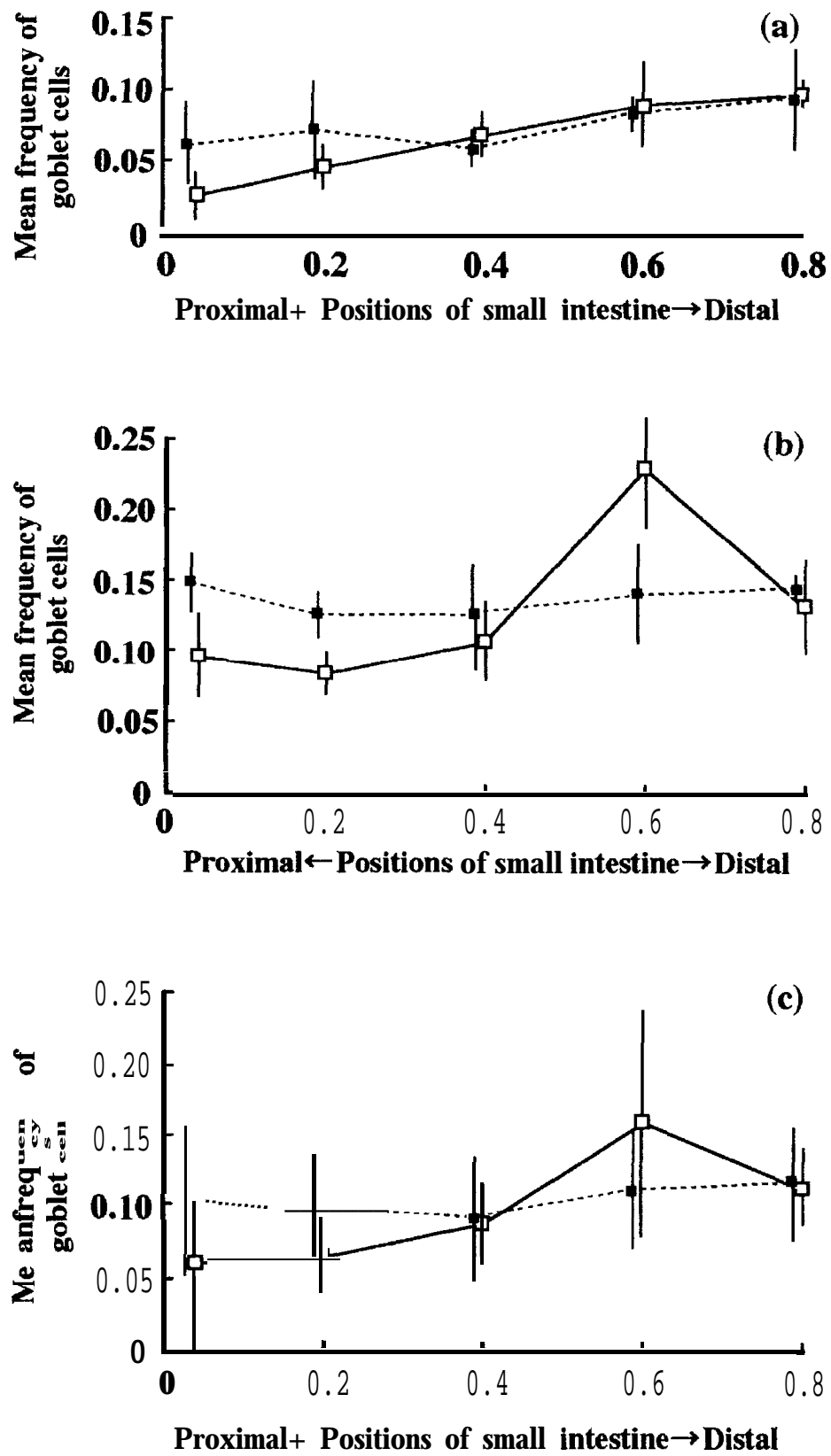

Fig. 3. Changes of frequency in appearances of goblet cells in accordance with the five positions from the proximal to distal side of the small intestines. Each graph indicates the changes in villi (a), crypts (b), and overall (c), respectively. Vertical bars represent standard deviations. - -..W, Apodemus argenteus; $\square-\square$, A. speciosus. 
the appearance of several Paneth's cells and the intensity of the reaction of the cytoplasm in the basal side of those cells to haematoxylin were not qualitatively different in the two species.

The goblet cells of the small intestines in both species were conspicuously identified with PAS (Figs 1 and 2). The microphotographs illustrate that the goblet cells were distributed sparsely in the villi and densely in the crypts. Compared to A. speciosus, in $A$. argenteus a large number of the cells in the crypts showed a more intensive reaction to the PAS technique.

Mean values of the frequency of appearance of goblet cells in the villi in the small intestines were 0.073 (s.d. $=0.027$ ) for $A$. argenteus and 0.065 (s.d. $=0.031$ ) for $A$. speciosus. Furthermore, in the crypts the mean values of $A$. argenteus and $A$, speciosus were 0.137 (s.d. $=0.027$ ) and 0.129 (s.d. $=0.060$ ), respectively; the standard deviation in A. speciosus was more than twice that in $A$. argenteus. The mean ratio of the frequency of the goblet cells in the crypts to that in the villi was 1.94 in A. argenteus and 1.73 in $A$. speciosus, accordingly, goblet cells of $A$. argenteus were concentrated more intensively in the crypts than those of $A$. speciosus (U-tests, $p<0.05$ ).

In comparison with frequency of appearance of goblet cells in the villi in relation to the five positions from the proximal to distal end of the small intestines, the values of the standard deviations were small at each of the five positions in both species. Especially, in $A$. argenteus, there was little change in the values extending over the whole small intestine (Fig. 3). In the crypts, the frequency of appearances of goblet cells was higher in $A$. argenteus than in $A$. speciosus at most positions of the small intestine. Additionally, those in the villi were rather homogeneously similar between the two species.

\section{DISCUSSION}

Ratios of animal food in the stomachs of $A$. speciosus were often similar to those in $A$. argenteus, or were higher in some cases than in $A$. argenteus because of great variations in the ratio in each the species (Igarashi, 1972; Mizushima and Yamada, 1974; Ota et al., 1977). Generally, it has been suggested that A. argenteus depends on animal food more than $A$. speciosus (Tachikawa and Murakami, 1976; Maeda et al., 1984). In each of our feeding experiments which varied both the benefit and cost of foraging, values of Ivlev's selective index and Jacobs's index of insects in A. argenteus were significantly greater than in A. speciosus. The differences were greater in the two experiments using motile insects, M.satsumaensis and $M$.domestica, than in the others using parasitised acrons. Previous research showed that food habits of Apodemus mice in Japan were more insectivorous than those of the same genus in Europe (Tachikawa and Murakami, 1976). Our results support the belief that $A$. argenteus depend on animal food more than $A$. speciosus.

Values of CL/SIL have been found to be higher in herbivorous Microtinae, Microtus montebelli, Clethrionomys nufocanus bedfordiae, and Eothenomys smithii and lower in four species of the genera Mus and Rattus, which feed on nutritious food in areas close to human, and granivorous and insectivorous $A$. argenteus and $A$. speciosus have moderate values of CL/SIL with slightly higher values in $A$. speciosus than in $A$. argenteus 
(Miyao, 1970). Our measurements also showed that both CL/ TL and CL/SIL were significantly higher in A. speciosus than in A. argenteus, and were consistent with the above view. Considering that there were no significant differences between the two species in the scaling of CL and cube root of body weight, it is implied that this distinction as to $\mathrm{CL}$ is very obscure.

Under reproductive conditions, A. argenteus uses more homogeneous microhabitats than A. speciosus (Shioya et al., 1992). A. argenteus is relatively selective in its nutrient demand. Further, the body weight of $\mathbf{A}$. argenteus is 0.3 to 0.5 times that of $\mathbf{A}$. speciosus and the basal metabolic rate $(3.18 \mathrm{ml} \mathrm{O} / \mathrm{g} \cdot \mathrm{h})$ of $\mathbf{A}$. argenteus is approximately twice as large as that $(1.57 \mathrm{ml} \mathrm{O} / \mathrm{g} \cdot \mathrm{h})$ of A. speciosus (Sekijima, 1993). On this basis it is predicted that mammals having higher metablolic rates require more nutritious foods (Jarman, 1974; Kleiber, 1975). From this, it follows that A. argenteus tends to require animal protein.

Comparison of the cells of the mucous layer and the fundus gland of the stomach revealed no substantial differences between the two species. However, the ratio of the thickness of the fundus gland region to the whole thickness in A. argenteus was larger than that in A. speciosus. Also, the ratio of the thickness of the region showing a high density of chief cells which produce pepsinogen, a precursor of pepsin, to the whole thickness in A. argenteus was superior to A. speciosus. These facts suggest that the gastric organ of $\mathbf{A}$. argenteus is more adapted to proteinic digestion than that of $\mathbf{A}$. speciosus.

The function of goblet cells in the intestinal tract has not yet been completely clarified. However, it is indisputable that the mucoprotein and acidic sulfatemucopolysaccharide secreted from the cells have the function of lubricating and protecting the mucosal epithelium (Kurosumi et al., 1981). It is recognized that the more insectivorous species in the Chiroptera (Pteropodidae, Vespertilionidae, Rhinolophidae, Hipposideridae and Phyllostomatidae) have a higher density of cells in the stomach which stain with PAS (Kamiya and Pirlot, 1975). In Microtus, an herbivorous vole species, the number of these cells is extremely small (Golley, 1960). This difference seems to show the importance of their function in protection against autolysis in animals feeding on higher proteinic foods.

In this connection, the distribution of goblet cells stained with PAS in A. argenteus was denser and more homogeneous at most positions of the small intestine than in $\mathbf{A}$. speciosus. This fact suggests that A. argenteus depends on more homogeneous and proteinic foods, and is consistent with the results of our feeding experiments. In A. argenteus, territoriality and monogamy have been observed (Oka, 1992). These characters are consistent with the restrictions in resource utilization in this species because such restrictions would reduce the qualitative heterogeneity of habitats which affects mating systems in animals (Emlen and Oring, 1977). In contrast with A. argenteus, in A. speciosus the large variation in distribution of goblet cells at different positions in the small intestine of individuals seems to support adaptation for euryphagous behaviour.

A. argenteus has a smaller body weight and a smaller stomach volume than $\mathbf{A}$. speciosus. Therefore, A. argenteus needs to increase absorptivity. The fact that the distribution of goblet cells in this species are concentrated in the crypts may be adaptive for increasing the number of goblet cells without extremely decreasing 
absorptivity. In small mammals, there are in fact correlations between mean ratio of mucosal surface area to serosal area in the small intestine and the degree of dependence on animal foods (Barry, 1976). Therefore, the tendency to depend on animal foods in A. argenteus is consistent with the distribution pattern of goblet cells. In general, quality of diet affects the ratio of goblet cells to mucosal epithelium cells in small intestines (Kurosumi et al., 1981). Considering the results from our feeding experiments, it seems reasonable to suppose that differences in distribution patterns of goblet cells between the two species reflect variances in their food habits. This implication may propose that there are substantial differences between the two A podemus species in the nutritional components of diet.

The above implies that histological characters in these two woodland Apodemus species reflect qualitative differences in potential food habits. The smaller A. argenteus depends on animal foods, while A. speciosus is not completely adaptive to absorption of animal foods and has promoted more euryphagous characteristics. It is suggested that these differences in potential food habits are related to the traits of foraging behavior, habitat utilization and territoriality in the two species.

\section{ACKNOWLEDGEMENTS}

We would like to thank the staff and graduate students of Zoological Laboratory, Faculty of Agriculture, Kyushu University for their facilities; special thanks are due to Dr. R. Peters, Department of Forestry, Wageningen Agricultural University, Nether lands, Dr. S. Lawson, and Ms. Barbara Andre for thoughtful and helpful comments on earlier draft of the manuscript.

\section{REFERENCES}

Barry, R. E. 1976 Mucosal surface areas and villous morphology of the small intestine of small mammals: functional interpretations. J. Mamm., 57: 273-290

Emlen, S. T. and L. W. Oring 1977 Ecology, sexual selection, and the evolution of mating systems. Science, 197: 215-223

Golley, F. B. 1960 Anatomy of the digestive tract of Microtus. J. Mamm., 41: 89-99

Hansson, L. 1985 The food of bank voles, wood mice and yellow -necked mice. Symp. Zool. Soc., Lond., No. 55: 141-168

Holisova, V. 1975 The food eaten by rodents in reed swamps of Nesyt fishpond. Zool. Listy, 24: 223-237

Horner, E., J. M. Taylor and H. A. Padykula 1965 Food habits and gastric morphology of the grasshopper mouse. J. Mamm., 45: 513-535

Igarashi, B. 1972 The food eaten by red-backed vole, Clethrionomys rufocanus bedfordiae in natural todo-fir forest land-Growth of sasa-bamboo. Ann. Rep. Hokkaido Bmn., Gov. For. Exp. St. 1971: 67-74 (in Japanese with English summary)

Ivlev, V. S. 1961 Experimental Ecology of the Feeding of Fishes, Yale Univ. Press, New Haven

Jacobs, 0. L. R. 1974 Introduction to Control Theory. Clarendon Press, Oxford

Jarman, P. J. 1974 The social organization of antelope in relation to their ecology. Behaviour, 478: 215-266

Kamiya, T. and P. Pirlot 1975 Comparative gastric morphology of old world bats. I. In light 
microscopy. J.Mamm. Soc. Japan, 6: 145-154

Kleiber, M. 1975 The fire of life: In An Introduction to Animal Energetics. New York, Krieger

Kurosumi, K., I. Shibuichi and H.Tosaka 1981 Ultrastructural studies on the secretory mechanism of goblet cells in the rat jejunal epithelium. Arch. Histol.Jap., 44: 263-284 (in Japanese)

Liithje, B. 1976 Vergleichend funktionell - anatomische und histochemische Untersuchungen am Magen von mitteleuropaischen Murinae (MurRay 1866) and Microtinae (Miller 1986) (Rodentia). Zool.Jb.Anat., 96: 451-512 (in German with English abstract)

Maeda, M., B. Igarashi and S. Mizushima 1984 Food habit. In Study on Wild Murid Rodents in Hokkaido (K. Ota ed.), Hokkaido Univ. Press, Sapporo (Japan), pp. 119-138 (in Japanese)

Martin, B. F. 1961 The goblet cell pattern in the large intestine. Anat. Rec., 142: 1-15

M'Closkey, R. T. 1976 Community structure in sympatric rodents. Ecology, 57: 728-739

Miyao, T., T. Kitazawa and M. Morozumi 1960 On the relations of the length of large intestine and caecum against the length of small intestine in rats. Zool.Mag., 69: 19-24 (in Japanese with English résumé)

Miyao, T. 1970 Animal Ecology -Basic Structure of Animal Community. Chi - iki - bunka - kenkyu sho, Funabashi (Japan) (in Japanese)

Mizushima, S. and E.Yamada 1974 Distribution and food habit of rodent species in farmland in Hokkaido. Jap. J. appl. Ent. Zool., 18: 81-88 (in Japanese with English synopsis)

Oka, T. 1992 Home range and mating system of two sympatric field mouse species, Apodemus speciosus and A podemus argenteus. Ecol. Res., 7: 163-169

Ota, K., H. Abe, T. Kobayashi, Y. Fujimaki, S. Higuchi, B. Igarashi, T. Kuwahata, M. Maeda, M. Ueda and T. Takayasu 1977 A synecological study of murid rodents. Res. Bull. Col.Exp.For., Col. Agr., Hokkaido Univ., 34: 119-159 (in Japanese with English summary)

Rosenzweig, M. L. 1981 A theory of habitat selection. Ecology, 62: 327-335

Rosenzweig, M. L. 1991 Habitat selection and population interactions: the search for mechanism. Am. Nat., 137: S5-S28

Sekijima, T. 1993 Differences of habitat use pattern and interrelationships in Apodemus argenteus and A.speciosus. Ph. D. dissertation, Univ. of Tokyo

Shioya, S., S. Shiraishi and T. A. Uchida 1990 Microhabitat segregation between A podemus argenteus and A. speciosus in northern Kyushu. J. Mamm.Soc. Japan, 14: 105 -118

Shioya, S., S. Shiraishi and T. A. Uchida 1992 Microhabitat use according to reproductive condition in two Apodemus species. J.Mamm.Soc. Japan, 17: 1-10

Sone, K. 1990 Functional responses to food resources of wood mice, Apodemus speciosus TEMMINCK and A podemus argenteus TEMmiNCK. J.Jpn. For. Soc., 72: 321-328

Suzuki, K., H. Nagai, H. Inagaki and H. Tamate 1986 Comparative morphology of gastric mucosa in Primates: Correlation of food habits. J. Mamm.Soc. Japan, 11: 45-55

Tachikawa, K. and 0. Murakami 1976 On the food utilization of the Japanese wood mouse Apodemus speciosus (Mammalia: Muridae). Physiol. Ecol. Japan, 17: 133-143 (in Japanese with English synopsis). 